\title{
HOPE for the Pell? Institutional Effects in the Intersection of Merit-Based and Need-Based Aid
}

\author{
Larry D. Singell, Jr.,* Glen R. Waddell, $†$ and Bradley R. Curs $\ddagger$
}

\begin{abstract}
Prior empirical evidence finds that general enrollment effects of merit-aid programs such as the Georgia Helping Outstanding Pupils Educationally (HOPE) scholarship are large and significant, while the effects of need-based aid programs such as the Pell grant are modest and often insignificant. This paper uses new panel data on Pell awards to examine the influence of the Georgia HOPE scholarship on needy-student enrollments. We demonstrate that the introduction of merit aid in Georgia generally improves the college access of needy students and has been leveraged into greater federal Pell assistance. While institution-specific increases in both Pell enrollment and funding are largest at two-year and less selective four-year institutions, the results suggest that Pell students are not crowded out of more selective schools by HOPE's intent to retain the best Georgia high school students, as might have been anticipated.
\end{abstract}

\section{JEL Classification: I21, I28, J24}

\section{Introduction}

There is increasing concern by policy makers and administrators regarding the access of financially needy students to higher education. In particular, two trends with regard to need-based aid have been documented as critical—Pell grants representing a decreasing share of the average financial aid package (Ehrenberg 2000) and students increasingly relying on unsubsidized loans to finance college (Duffy and Goldberg 1998; McPherson and Schapiro 1998; Dynarski 2003). Concurrently, state governments and universities have begun to place greater emphasis on non-need-based aid in an attempt to attract and retain the best students (McPherson and Schapiro 1994). Since receiving federal need-based aid often precedes and precludes receipt of other forms of state aid, non-need-based aid programs such as Georgia's Helping Outstanding Pupils Educationally (HOPE) scholarship afford a relative advantage to the financially well to do (e.g., Clotfelter 2004). The purpose of this paper is to examine whether and how the introduction of the HOPE scholarship affected the enrollment of Pell students within the higher educational system of Georgia. This paper therefore sheds light on whether broad-based, merit-aid programs have harmed the access objectives of needy students.

\footnotetext{
* Department of Economics, University of Oregon, Eugene, OR 97403-1285, USA; E-mail 1singell@uoregon.edu.

$\dagger$ Department of Economics, University of Oregon, Eugene, OR 97403-1285, USA; E-mail waddell@uoregon.edu; corresponding author.

\$ Department of Educational Leadership and Policy Analysis, University of Missouri-Columbia, Columbia, MO 65211, USA; cursb@missouri.edu.

We thank Julie Hotchkiss and three anonymous referees for comments and contributions to this paper, as well as participants at the NBER Higher Education Working Group, April 2004, and the 2004 meeting of the Southern Economic Association. Any errors or omissions are the responsibility of the authors.

Received May 2005; accepted November 2005.
} 
Among state-level, non-need-based aid programs, Georgia's HOPE scholarship is the most generous, having dispensed over $\$ 2.7$ billion in aid to more than 850,000 students since the program's inception in 1993. Conditional on graduating from a Georgia high school with a B average or better, the HOPE scholarship covers tuition, fees, and book expenses for those attending Georgia public postsecondary institutions. Overall, the HOPE scholarship represents a significant source of meritbased financial aid within Georgia.

Existing research on the Georgia HOPE scholarship indicates that the introduction of meritbased aid has significantly increased overall college attendance. For example, Cornwell, Mustard, and Sridhar (2006) use Integrated Postsecondary Education Data System (IPEDS) to show that the HOPE scholarship has increased the college enrollment rate of first-time freshmen by roughly $6 \%$ in Georgia relative to the surrounding southern states. Likewise, with Current Population Survey (CPS) data on 18- to 19-year-old youth, Dynarski (2004) finds that the HOPE scholarship has increased Georgia students' likelihoods of attending college by $7 \%$ to $9 \%$ relative to the treatment group in other southern states. The literature, therefore, provides evidence regarding HOPE's efficacy for broad student populations.

In general, despite the size of the Pell program and the significant changes in the environment facing needy students targeted by Pell resources, prior research has noted a paucity of formal evidence associated with how the movement toward non-need-based aid has affected their access to a college education (e.g., Balderston 1997; Clotfelter 2004). While not measuring need directly, prior work has shown that the impact of merit aid in Georgia appears larger among relatively higher income groups and among institutions that attract relatively well-to-do students. Specifically, Dynarski (2004) finds a $12 \%$ post-HOPE enrollment effect for white students, but no increase in African-American enrollments. Cornwell, Mustard, and Sridhar (2006) find that the enrollment effects of HOPE are concentrated among four-year (as opposed to two-year) institutions. Further, prior literature on Pell enrollments also leaves some question about how responsive needy students are to increases in aid generally and the types of institutions at which responses are potentially found (e.g., Hansen 1983; Manski and Wise 1983; Kane 1995; Seftor and Turner 2002).

Collectively, the literature's silence regarding the influence of merit aid on needy-student outcomes, the size and increasing prominence of non-need-based programs, and the suggestion in the literature that needy students may be less responsive to increases in aid, are cause for potential concern. Using new data on annual Pell enrollments by institution that span the 1993 introduction of HOPE (i.e., 1988 to 1997), we document differential responses to the HOPE scholarship based on a well-defined and consistent measure of need that is exogenous to institutions. Contrary to the findings of prior work, we find that the number of Pell recipients increased at institutions in Georgia after HOPE, as compared with other southern universities, consistent with broad merit-based scholarship programs improving college access for needy students.

In addition to our analysis of enrollment, we find that HOPE has differential effects on average and total Pell receipts in Georgia relative to other southern institutions. Specifically, the average Pell award is lower at Georgia institutions after HOPE, suggesting that HOPE draws students of lesser need into the Pell program. Moreover, we find that total Pell revenues increase in Georgia relative to other southern institutions after HOPE, which suggests that broad meritaid programs are effective at leveraging scholarships with greater federal funding paid to needy students who may have not otherwise attended college. Contrary to the findings of Cornwell, Mustard, and Sridhar (2006) for the broader population of college students, our analysis indicates that institution-level increases in Pell student enrollment and Pell aid occur at both two-year and four-year schools. 
The paper proceeds as follows. In section 2, we describe the institutional details that are pertinent to our empirical analysis and that motivate our tests. Section 3 describes the data and empirical models of the institutional enrollment effects of the HOPE scholarship. The observed enrollment effects of HOPE in section 3 motivate our analysis of average and total Pell revenue accruing to Georgia institutions, which we explore in section 4. Finally, section 5 concludes.

\section{Institutional Attributes of the Pell Program and the Georgia HOPE Scholarship}

To receive federal aid in the form of a Pell grant, a student must first complete a Free Application for Federal Student Aid (FAFSA) form, which provides financial aid administrators with the information needed to determine the eligibility and size of an applicant's Pell grant. The award value is formulaic, determined by the student's expected family contribution (EFC) and the institution-specific cost of attendance (COA), which includes tuition, room, board, and other expenses such as books and travel. For dependent students, the EFC is a function of parent income and wealth and the number of siblings in college. Conditional on being above the federally mandated minimum grant, the level of an individual student's grant in any given year is the minimum of (i) the difference between the federal maximum Pell grant and the student's EFC; (ii) the difference between the institution's COA and the student's EFC; and (iii) prior to 1993, 60\% of the institution's COA. ${ }^{1}$ Given the sequential distribution of aid-federal preceding state preceding institution - in no way is a student's Pell status or award value dependent on state or institution aid. Except in the case where low-cost institutions could potentially increase their COA in response to HOPE, Pell status and award values can safely be exploited as exogenous to the introduction of HOPE. Further, Long (2002) studies a time series of Georgia institutions spanning the introduction of HOPE and finds no significant tuition response at public universities, which we also confirm in our data. ${ }^{2}$

All else equal, the advent of Georgia's HOPE scholarship increased the likelihood that the average in-state high school student received financial aid in attending college within the State of Georgia. It follows that the HOPE scholarship lowered the expected cost of attending Georgia colleges and universities for the average in-state high school student. Thus, the empirical analysis tests the expectation that the HOPE scholarship has induced a general increase in the enrollment of both Pell and non-Pell students in Georgia, which is presented in section 3.

Given our particular interest in the prospects of needy students, two key dimensions of the scholarship are integral to our current analysis and may have generated an asymmetric response to HOPE across levels of need. First, over the period of our sample, low-income students were required to complete a FAFSA, and the receipt of a Pell award preceded the HOPE scholarship and reduced its

\footnotetext{
${ }^{1}$ The percentage cap on Pell grants was 50\% from 1973 through 1984 and 60\% from 1985 through 1992. Following the 1992 Higher Education Amendments, the percentage cap was abolished. Although the percentage-cap rule was changed in the same year that HOPE was introduced, the inclusion of year indicators should absorb the effect of this policy change since it occurred in all control states and Georgia.

${ }^{2}$ Former Education Secretary William Bennett speculated in a 1987 New York Times article that the cost of college may not decrease with the government provision aid if colleges and universities raise tuition in response. However, prior evidence with regard to the Bennett hypothesis is mixed (e.g., Long 2002; Rizzo and Ehrenberg 2003; Singell and Stone 2006). Our data suggest that if anything, tuition decreased at the average institution in Georgia following HOPE, across both four- and two-year schools. Moreover, while we exclude tuition from our empirical model, we find that the inclusion of tuition (contemporaneous or lagged) does not quantitatively or qualitatively affect the conclusions of the empirical analyses.
} 
value dollar for dollar. ${ }^{3}$ It follows that the HOPE scholarship was relatively generous to the financially well to do, who potentially gained a merit award without the implied reduction in need-based aid. ${ }^{4}$ Second, being merit-based, HOPE is by definition relatively generous to the academically able, which might alone be expected to expand competition over access for a given quality institution. Accordingly, the introduction of HOPE granted to some of the most financially and academically able high school students in Georgia a relative advantage in the financing of college by lowering their costs of attending college in comparison with those with fewer financial resources, who were more likely to qualify for need-based aid programs. ${ }^{5}$

While the predicted behavioral responses to HOPE are strictly at the student level, data limitations restrict our analysis to institutions. As such, we are unable to directly address potential asymmetries across an ex ante distribution of student ability. However, any systematic change in the ex post distribution of college costs brought about by the introduction of the HOPE scholarship may have nonetheless changed the distribution of needy students over the quality spectrum of universities in Georgia. ${ }^{6}$ Specifically, the scholarship may have increased the propensity for the most academically able students, who may otherwise have attended out-of-state schools, to remain in state and for nonneedy but academically able students to substitute into selective, potentially higher cost institutions within Georgia. Indeed, prior work has shown a post-HOPE improvement in the quality of students attending Georgia institutions as measured by their relative SAT performance (e.g., Cornwell and Mustard 2002). We examine the potential asymmetric impact of HOPE across the quality hierarchy of Georgia institutions in section 3.

The implied enrollment effects of the HOPE on Pell recipients also have implications regarding the average Pell award per student and total Pell revenues at Georgia institutions. Specifically, the requirement for low-income students to complete the FAFSA to receive HOPE would tend to draw less needy students into the pool of Pell recipients by encouraging students who might not have applied for federal support either because they did not expect to receive a grant or because the value of the expected grant was not sufficient to warrant the effort. It follows that HOPE might be expected to lower the average Pell award in Georgia. On the other hand, the downward pressure on average Pell awards might be offset by HOPE encouraging needy students to attend more costly institutions (e.g., four-year vs. two-year schools) that could possibly qualify them for higher Pell awards. Thus, we examine the potential for the HOPE scholarship yielding asymmetric effects on average Pell awards across selectivity in section 4. Finally, because the response of total Pell revenues to HOPE depends

\footnotetext{
${ }^{3}$ In 1995, the initial requirement for all HOPE applicants to simultaneously file a FAFSA was maintained only for applicants with household incomes below $\$ 50,000$ and eliminated for others. The formal requirement to file a FAFSA in conjunction with any HOPE application was formally lifted in 2001, outside of our sample period. The HOPE application is now completed at little cost to applicants, with a few items of basic nature that can be entered electronically at www.gsfc.org/hope.

${ }^{4}$ For a short time the Georgia HOPE scholarship did have a maximum household income rule. Specifically, in the first year of the program (1993) a household income cap of $\$ 66,000$ was imposed, which was raised to $\$ 100,000$ the following year and eliminated entirely thereafter. Thus, while the relative advantage exists on average, the presence of such caps would restrict any advantage to those students with wealth high enough to not qualify for Pell but not so high as to be subject to the income cap, at least over the initial years of the scholarship. Note that the relaxed income cap should have no influence on Pell enrollments since the set of students for which the income cap was binding would not qualify for Pell assistance.

${ }^{5}$ Singell and Stone (2002) found that the introduction of a merit-based scholarship program at a large public university yielded a larger enrollment effect for relatively well-to-do students who could (academically and financially) choose to attend college out of state.

${ }^{6}$ Not having more detailed data also precludes the direct study of the attrition rates of needy students. For example, one might surmise that those of lower ability are among the two-thirds of students who, after initially qualifying for HOPE, lose their funding at the first checkpoint because of poor academic performance (for additional discussion, see Dee and Jackson 1999).
} 
on both enrollment and average Pell awards, each of which may vary asymmetrically with selectivity, total revenue responses are also examined separately in section 4 .

\section{Empirical Analysis of Pell and Non-Pell Enrollments}

\section{Sample Data and Preliminary Enrollment Specifications}

We draw from two main data sources to address the testable implications above: the IPEDS and institution-specific Pell award data, covering the period from 1988 through 1997, provided by the U.S. Department of Education. ${ }^{7}$ While one could argue that the sample years are chosen to evenly span the introduction of HOPE, it is also the case that other state-sponsored merit programs proliferate after 1997, which may compromise the integrity of the control group and difference-in-difference estimation. While the potential observations are the entire population of colleges and universities in the United States, we restrict our analysis to the southern U.S. states, which form a reasonable control group against which we measure the effects of HOPE on needy students, following the existing literature studying the effects of Georgia's HOPE scholarship (e.g., Dynarski 2004; Cornwell, Mustard, and Sridhar 2006). Since we are focused on the merit-based nature of HOPE, we discard non-degree-granting programs and define the sample as nonprofit institutions that offer at least an associate's degree. ${ }^{8}$ Subject to these conditions, discarding missing observations, and restricting the sample to those institutions with complete observations in at least three years before and three years after the introduction of HOPE, we analyze a sample of 7432 observations from 759 institutions in 15 southern states. State-level attributes are incorporated using U.S. Census data from the Bureau of Economic Analysis, Bureau of Labor Statistics, and the Southern Regional Education Board. ${ }^{9}$

Sample characteristics are reported in Table 1 and generally suggest that enrollments increased in Georgia with the introduction of HOPE relative to the other southern states. Specifically, total and Pell enrollment increased $10.1 \%$ and $24.4 \%$ from the pre- to the post-HOPE period in Georgia, respectively, whereas total and Pell enrollment growth was $3.2 \%$ and $12.1 \%$ in the other southern states. At the same time, average Pell awards fell in Georgia by $6.2 \%$ in the post- versus pre-HOPE period, compared with a $2.6 \%$ decline in the other southern states. Jointly, these results suggest that,

\footnotetext{
${ }^{7}$ IPEDS data are available from the National Center for Educational Statistics at nces.ed.gov.

${ }^{8}$ The HOPE grant, which applies to nondegree programs at two-year and less than two-year schools, has no merit requirement. Thus, our sample implies that the results cannot be explained by the presence of the HOPE grant.

${ }^{9}$ The original merged data consist of 5670 institutions over the nine-year period from 1988 to 1997 , for a total of 54,991 institution-year observations. Defining the control group for the Georgia HOPE scholarship as the states in the Southern Regional Education Board (SREB) restricts our sample to 1797 institutions (17,317 observations), of which 1033 are nonprofit institutions that offer at least an associate's degree, which yields a sample of 9751. While missing observations on total enrollment were imputed in some cases (167), imputing enrollment was not reasonable in 687 cases. These observations are therefore discarded, as are 629 where freshman enrollment was unavailable. Of the remaining 8435 observations, the number of Pell recipients enrolled was not reported (in 375 cases) or was reported as zero (in 15 cases). Naturally, these observations are also discarded, as are an additional 81 cases where the reported number of Pell students exceeds the reported enrollment of the institution. At this point the data consist of 7959 observations across 891 institutions. However, since our focus is on the effects of the introduction of the Georgia HOPE scholarship, we ensure each institution's existence for three years in the sample both prior to and following the scholarship's introduction. This leaves a sample size of 7432 observations over 759 institutions. The discarded institutions are more likely to be smaller, two-year institutions. However, the average Pell awards reported to these institutions are not significantly different from the sample retained for analysis. In considering the non-SREB institutions, there are no differences in size or in Pell characteristics, but non-SREB institutions are more likely to be private (43\% of the sample are private in non-SREB while $35 \%$ of SREB are private) and less likely to be historically black colleges and universities (HBCUs) (0.6\% are HBCUs in non-SREB while $10 \%$ of SREB are HBCUs).
} 
Table 1. Sample Characteristics: Georgia vs. Other Southern States

\begin{tabular}{lccccc}
\hline & \multicolumn{2}{c}{ Georgia } & & \multicolumn{2}{c}{ Other Southern States } \\
\cline { 2 - 3 } \cline { 5 - 6 } Independent Variable & Pre HOPE & Post HOPE & & Pre HOPE & Post HOPE \\
\hline Pell enrollment & 766.7 & 1014.6 & & 1070.2 & 1217.3 \\
& $(670.1)$ & $(870.0)$ & & $(1316.9)$ & $(1533.7)$ \\
Total enrollment & 3068.4 & 3412.7 & & 4262.4 & 4402.4 \\
& $(3893.3)$ & $(4061.7)$ & & $(5493.9)$ & $(5580.8)$ \\
Average Pell awards & 136.2 & 128.2 & & 133.6 & 130.2 \\
& $(21.3)$ & $(18.0)$ & & $(25.9)$ & $(16.6)$ \\
Total Pell revenue (10,000s) & 107.8 & 133.7 & & 146.7 & 161.5 \\
& $(100.6)$ & $(121.7)$ & & $(187.5)$ & $(212.4)$ \\
Two-year institution & 0.332 & 0.323 & & 0.447 & 0.443 \\
& $(0.472)$ & $(0.468)$ & & $(0.497)$ & $(0.497)$ \\
Selective institution & 0.204 & 0.201 & & 0.175 & 0.177 \\
& $(0.403)$ & $(0.407)$ & & $(0.380)$ & $(0.382)$ \\
Private (not-for-profit) institution & 0.411 & 0.431 & & 0.347 & 0.351 \\
& $(0.493)$ & $(0.496)$ & & $(0.476)$ & $(0.477)$ \\
Historically black institution & 0.132 & 0.139 & & 0.101 & 0.103 \\
& $(0.339)$ & $(0.346)$ & & $(0.301)$ & $(0.304)$ \\
Per capita personal income & $17,652.4$ & $18,731.2$ & & $17,228.0$ & $18,065.9$ \\
& $(141.0)$ & $(536.8)$ & & $(2224.0)$ & $(1987.5)$ \\
State population: & $208,811.8$ & $204,846.5$ & & $228,718.5$ & $225,157.5$ \\
18 to 19 year olds & $(7146.9)$ & $(7518.9)$ & & $(155,532.2)$ & $(164,134.2)$ \\
Number high school & $64,123.5$ & $63,157.9$ & & $72,437.7$ & $74,251.1$ \\
graduates, state & $(3186.3)$ & $(1362.2)$ & & $(47,944.0)$ & $(54,246.2)$ \\
Observations/number of institutions & $280 / 58$ & $288 / 58$ & & $3403 / 701$ & $3460 / 701$ \\
\hline
\end{tabular}

\footnotetext{
Variable means (and standard errors) are presented for the sample of 759 institutions used in subsequent analysis, over the period 1988 through 1997.
}

although Pell enrollment was generally increasing in the South, the HOPE scholarship is associated with a relative expansion of Pell enrollment that drew relatively less needy students into the Pell program. The empirical analysis examines whether this relative change in the number and need of Pell students remains after conditioning on all factors that might be expected to explain college enrollments.

Given existing literature, a natural point of departure for the analysis would be to model freshman Pell enrollment (e.g., Cornwell, Mustard, and Sridhar 2006). However, the U.S. Department of Education has no record of Pell enrollments by class for the years surrounding the introduction of Georgia's HOPE scholarship. Thus, to speak to the potential effects of aggregation, we model levels of freshman enrollment, $F_{i t}$, and total enrollment across all undergraduate classes, $T_{i t}$. In particular, before we turn to test the above predictions we model

$$
\ln F_{i t}=\alpha_{i}^{F}+\gamma_{t}^{F}+\beta^{F}(\mathrm{HOPE} \times \mathrm{GA})_{i t}+\lambda^{F} \mathbf{X}_{i t}+\varepsilon_{i t}^{F}
$$

and

$$
\ln T_{i t}=\alpha_{i}^{T}+\gamma_{t}^{T}+\beta^{T}(\mathrm{HOPE} \times \mathrm{GA})_{i t}+\lambda^{T} \mathbf{X}_{i t}+\varepsilon_{i t}^{T},
$$

for institution $i$ in year $t$. In Equations 1 and 2, $\alpha_{i}$ and $\gamma_{t}$ are institution and year fixed effects, respectively, and $\mathbf{X}_{i t}$ is a vector of state-level controls. Year effects are included in all specifications to capture potential variation not otherwise held constant, and the institution fixed effects control for time-invariant institutional characteristics. Following Cornwell, Mustard, and Sridhar (2006), we 
Table 2. Sensitivity of Freshman and Total Enrollments at Georgia Institutions with the Introduction of the HOPE Scholarship

\begin{tabular}{|c|c|c|c|c|}
\hline \multirow[b]{2}{*}{ Independent Variable } & \multirow{2}{*}{$\begin{array}{c}\log (\text { Freshman } \\
\text { Enrollment) Overall } \\
(1)\end{array}$} & \multicolumn{3}{|c|}{$\log$ (Total Enrollment) } \\
\hline & & $\begin{array}{l}\text { Overall } \\
\text { (2) }\end{array}$ & $\begin{array}{l}\text { Pell Only } \\
\text { (3) }\end{array}$ & $\begin{array}{l}\text { Non-Pell Only } \\
\text { (4) }\end{array}$ \\
\hline HOPE $\times$ GA institution & $\begin{array}{c}0.141 \\
(0.028)^{* * *}\end{array}$ & $\begin{array}{c}0.123 \\
(0.012)^{* * *}\end{array}$ & $\begin{array}{c}0.179 \\
(0.017) * * *\end{array}$ & $\begin{array}{c}0.088 \\
(0.019)^{* * * *}\end{array}$ \\
\hline $\log ($ per capita personal income $)$ & $\begin{array}{l}-0.188 \\
(0.246)\end{array}$ & $\begin{array}{c}0.127 \\
(0.110)\end{array}$ & $\begin{array}{c}-1.511 \\
(0.151)^{* * *}\end{array}$ & $\begin{array}{c}0.726 \\
(0.168)^{* * *}\end{array}$ \\
\hline $\log ($ mean weekly manufacturing wage $)$ & $\begin{array}{l}-0.170 \\
(0.249)\end{array}$ & $\begin{array}{c}0.073 \\
(0.111)\end{array}$ & $\begin{array}{c}0.632 \\
(0.153)^{* * *}\end{array}$ & $\begin{array}{c}0.105 \\
(0.170)\end{array}$ \\
\hline $\log$ (state population: 18 to 19 year olds) & $\begin{array}{c}0.807 \\
(0.193)^{* * *}\end{array}$ & $\begin{array}{c}0.153 \\
(0.086) *\end{array}$ & $\begin{array}{c}-0.730 \\
(0.118)^{* * *}\end{array}$ & $\begin{array}{c}0.515 \\
(0.131)^{* * *}\end{array}$ \\
\hline $\log$ (number high school graduates, state) & $\begin{array}{c}0.118 \\
(0.077)\end{array}$ & $\begin{array}{c}-0.060 \\
(0.034)^{*}\end{array}$ & $\begin{array}{c}0.240 \\
(0.047)^{* * *}\end{array}$ & $\begin{array}{c}-0.102 \\
(0.052)^{*}\end{array}$ \\
\hline Year fixed effect & Yes & Yes & Yes & Yes \\
\hline Institution fixed effect & Yes & Yes & Yes & Yes \\
\hline Constant & $\begin{array}{l}-2.125 \\
(3.572)\end{array}$ & $\begin{array}{c}4.738 \\
(1.590)^{* * *}\end{array}$ & $\begin{array}{c}23.282 \\
(2.189)^{* * *}\end{array}$ & $\begin{array}{c}-5.628 \\
(2.433)^{* *}\end{array}$ \\
\hline Observations/number of institutions & $7432 / 759$ & $7432 / 759$ & $7432 / 759$ & $7432 / 759$ \\
\hline$R^{2}$ (within) & 0.02 & 0.14 & 0.38 & 0.05 \\
\hline
\end{tabular}

Coefficient estimates are from fixed-effects models controlling for institution-specific unobserved heterogeneity. Dependent variables are $\log$ (enrollments), where enrollment means for columns 1 through 4 are 748, 4250, 3125, and 1125, respectively. The sample period is 1988 through 1997. Standard errors in parentheses.

* Significant at $10 \%$.

** Significant at $5 \%$.

*** Significant at $1 \%$

control for per capita income, manufacturing wage, number of 18 and 19 year olds, and number of high school graduates in the state. The results of estimating Equations 1 and 2 are presented in columns 1 and 2 of Table 2 .

In short, the estimated difference-in-difference coefficient in the institution-level fixed-effects specification of Equation 1 suggests that HOPE increased freshman enrollment by 15\%, while the use of total enrollment, in Equation 2, yields a predicted 13\% post-HOPE increase in enrollment. Thus, bias introduced through such aggregation appears to be minimal. Further, since HOPE was only made available to each year's freshman class, the first three years of the HOPE scholarship necessarily contribute only to a fraction of total enrollment, and the relative magnitudes of the estimated coefficients are not surprising.

\section{Pell versus Non-Pell Enrollments}

Having established the robustness of the estimates to the use of total versus freshman enrollments, we now turn to address the testable implications of section 2. Following Equations 1 and 2, we estimate the following fixed-effects models of institution-level enrollment by Pell status:

$$
\ln P_{i t}=\alpha_{i}^{P}+\gamma_{t}^{P}+\beta^{P}(\mathrm{HOPE} \times \mathrm{GA})_{i t}+\lambda^{P} \mathbf{X}_{i t}+\varepsilon_{i t}^{P}
$$

and

$$
\ln N_{i t}=\alpha_{i}^{N}+\gamma_{t}^{N}+\beta^{N}(\mathrm{HOPE} \times \mathrm{GA})_{i t}+\lambda^{N} \mathbf{X}_{i t}+\varepsilon_{i t}^{N},
$$


where $P_{i t}$ and $N_{i t}$ are number of Pell and non-Pell recipients registered at institution $i$ in year $t .^{10}$ The results of estimating Equations 3 and 4 are presented in columns 3 and 4 of Table 2 .

The estimated coefficients on control variables offer some insights into differences between Pell and non-Pell students. For example, a $\$ 1000$ increase in per capita income in a state is associated with a $1.5 \%$ reduction in Pell enrollment but increases non-Pell enrollment by $0.7 \%$, suggesting that increases in income reduce the number of students who are eligible for federal aid. A $1 \%$ increase in the manufacturing wage increases the probability that Pell students attend college by approximately $0.6 \%$, but yields no significant enrollment effect for non-Pell students. Higher manufacturing wages may improve access of needy students if this sector is a primary employer of their parents, but higher wages will not necessarily have this effect if they provide better prospects for entry-level jobs for lowincome high school graduates. Comparable to the findings of Card and Lemieux (2000) for overall college enrollments, we find that a $1 \%$ increase in the number of 18 to 19 year olds reduces the enrollment of Pell students by $0.7 \%$, whereas a $1 \%$ increase in the number of high school graduates increases Pell enrollment by $0.3 \%$.

With respect to our variable of interest, columns 3 and 4 reveal significant asymmetries in the estimated effect of HOPE's introduction. Specifically, Georgia institutions realize an average $20 \%$ increase in Pell enrollments in the four years following the introduction of HOPE. Thus, unlike prior literature that shows little or no enrollment elasticity for needy students in response to need-based aid (e.g., Hansen 1983; Kane 1995), we find a substantial enrollment response to the HOPE scholarship for needy students. Further, while non-Pell enrollments respond by an average of $9 \%$, our results suggest that population-wide responses may hide significant asymmetry in responsiveness with general effects being driven more by needy students.

Insofar as one interprets this empirical regularity in terms of a real enrollment effect-needy students accessing college after HOPE when they may not have prior to HOPE—recall that a generous merit-based scholarship would be expected to draw more low-income students into college simply because needy students are more likely to be credit constrained and would have a lower propensity to attend college without the aid guarantee and backfilling of HOPE to federal aid programs such as Pell. On the other hand, because low-income students were required to complete a FAFSA to be eligible for HOPE, the HOPE scholarship may have also induced some marginally needy students who would have attended college without federal aid to apply and receive a Pell award, which would reduce the predicted enrollment effect of HOPE for non-Pell students. Thus, while certain marginally needy students who change status may contribute to more of an accounting effect than an enrollment effect, the $11 \%$ difference between the observed enrollment effects for Pell and non-Pell students is unlikely to be fully attributable to such status changes. In fact, the real enrollment effect might be expected to be overstated for nonneedy versus needy students who are relatively likely to be retained in Georgia by the HOPE scholarship (i.e., to change status from outof-state to in-state student). This is explored more directly in subsequent analyses of institution-level award values and total Pell revenue.

\footnotetext{
${ }^{10}$ While it would be natural to anticipate separate state controls, the fact that we control for all time-invariant characteristics with institution fixed effects absorbs any state-specific level effects. Further, one might anticipate the inclusion of $\mathrm{HOPE}_{t}$ itself. However, by fitting the model with separate year indicators, we have already absorbed potential level effects in posttreatment years. We note, however, that restricting the year controls to be equal in posttreatment years (i.e., specifying the model as $\alpha_{i}+\delta \mathrm{HOPE}_{t}+\beta(\mathrm{HOPE} \times \mathrm{GA})_{i t}+\lambda \mathbf{X}_{t}+\varepsilon_{i t}$ instead of $\alpha_{i}+\gamma_{t}+\beta(\mathrm{HOPE} \times \mathrm{GA})_{i t}+\lambda \mathbf{X}_{t}+\varepsilon_{i t}$, which includes nine individual year dummies) yields comparable results, both qualitatively and in terms of measurable impact.
} 
Table 3. Sensitivity of Enrollments at Georgia Institutions with the Introduction of the HOPE Scholarship

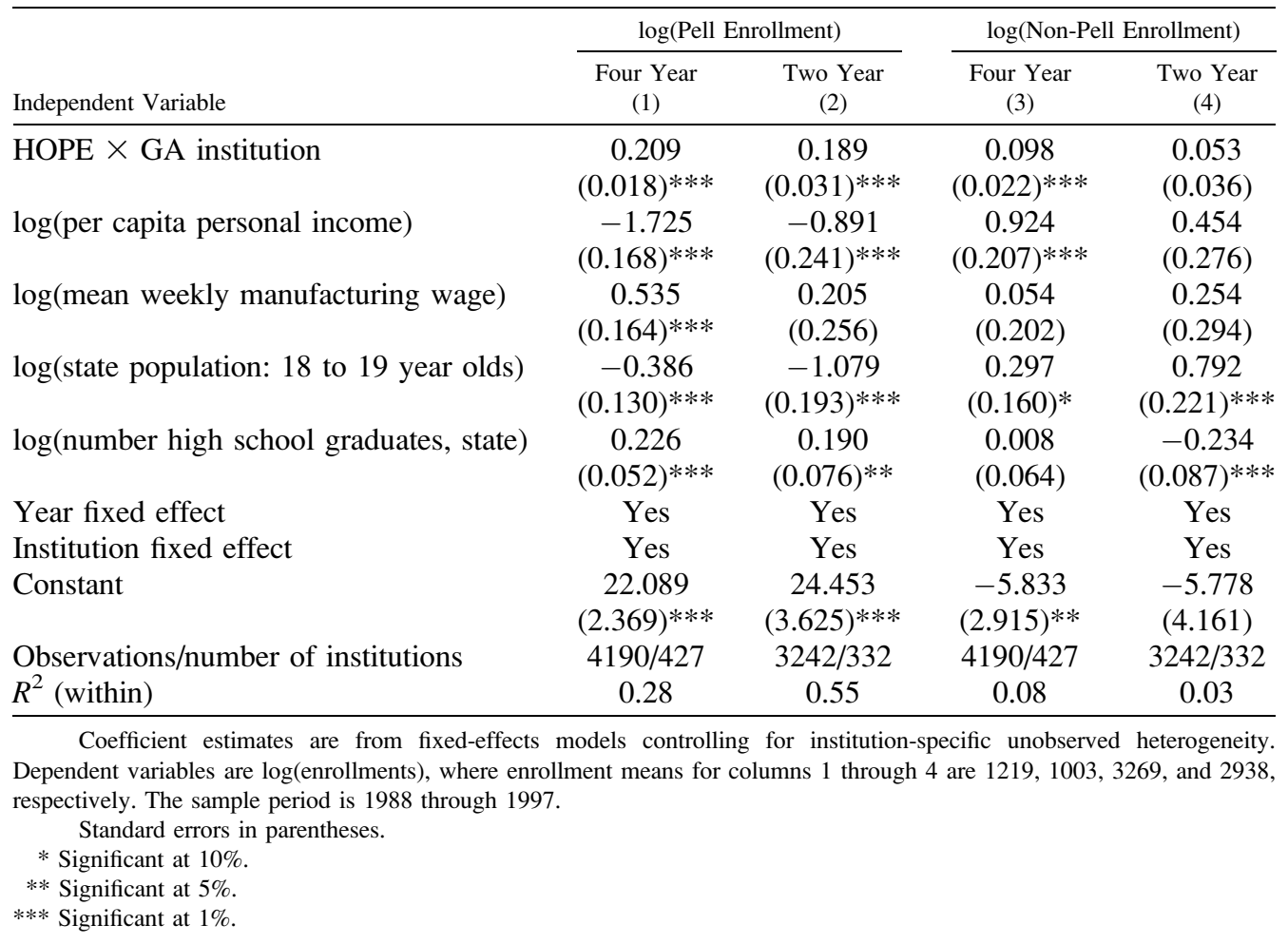

\section{Qualitative Differences in Enrollment Effects}

While the substantial increase in needy-student enrollment is alone notable, the average effect identified through the estimation of Pell enrollments hides the potential for differential Pell enrollment responses across Georgia schools. To expose any systematic enrollment responses across different types of institutions, we first reestimate Equations 3 and 4 for four-year and two-year institutions. Overall, the results in Table 3 continue to show that the enrollment effect of HOPE is significantly larger for Pell than for non-Pell students. However, estimation results reveal systematic differences in enrollment patterns at two- versus four-year institutions across Pell status.

For Pell students, in the five years subsequent to HOPE's introduction, enrollment is $23 \%$ higher at four-year Georgia institutions than at comparable southern institutions and $21 \%$ higher at two-year institutions. On the other hand, difference-in-difference estimates for non-Pell students indicate a 10\% enrollment effect at four-year institutions and no significant effect at two-year schools. For non-Pell enrollments, our findings are consistent with those in Cornwell, Mustard, and Sridhar (2006) for the full population of college students, indicating no overall enrollment effect at two-year schools. However, since our analysis affords the separation of Pell students from the total population of enrollees, our results suggest that a very different response exists among needy students and that there are potentially large effects among the needy at both four- and two-year institutions.

With the specific claim that HOPE may have given an advantage to both the academically and financially able, the potential crowding effect across school quality may introduce ambiguity in the net change in Pell enrollment at selective institutions. Given this, and the observed differences across the four-year and two-year classification of institution, we further analyze the variation in enrollment 
Table 4. Sensitivity of Enrollments at Georgia Four-Year Institutions with the Introduction of the HOPE Scholarship

\begin{tabular}{|c|c|c|c|c|c|c|}
\hline \multirow[b]{2}{*}{ Independent Variable } & \multicolumn{3}{|c|}{$\log ($ Pell Enrollment $)$} & \multicolumn{3}{|c|}{$\log ($ Non-Pell Enrollment $)$} \\
\hline & $\begin{array}{l}\text { Pooled } \\
\text { (1) }\end{array}$ & $\begin{array}{l}\text { Public } \\
\text { (2) }\end{array}$ & $\begin{array}{l}\text { Private } \\
\text { (3) }\end{array}$ & $\begin{array}{l}\text { Pooled } \\
\text { (4) }\end{array}$ & $\begin{array}{l}\text { Public } \\
\text { (5) }\end{array}$ & $\begin{array}{l}\text { Private } \\
\text { (6) }\end{array}$ \\
\hline HOPE $\times$ GA institution & $\begin{array}{c}0.269 \\
(0.021)^{* * *}\end{array}$ & $\begin{array}{c}0.333 \\
(0.020)^{* * * *}\end{array}$ & $\begin{array}{c}0.188 \\
(0.034)^{* * * *}\end{array}$ & $\begin{array}{c}0.124 \\
(0.025)^{* * * *}\end{array}$ & $\begin{array}{c}0.042 \\
(0.019)^{* *}\end{array}$ & $\begin{array}{c}0.229 \\
(0.044)^{* * *}\end{array}$ \\
\hline $\begin{array}{l}\text { HOPE } \times \text { GA institution } \times \\
\text { Selective }\end{array}$ & $\begin{array}{c}-0.195 \\
(0.035)^{* * *}\end{array}$ & $\begin{array}{c}-0.300 \\
(0.040)^{* * *}\end{array}$ & $\begin{array}{l}-0.081 \\
(0.052)\end{array}$ & $\begin{array}{c}-0.085 \\
(0.043)^{* *}\end{array}$ & $\begin{array}{c}-0.103 \\
(0.038) * * *\end{array}$ & $\begin{array}{l}-0.150 \\
(0.068)^{* *}\end{array}$ \\
\hline $\begin{array}{l}\log \text { (per capita personal } \\
\text { income) }\end{array}$ & $\begin{array}{c}-1.724 \\
(0.167)^{* * *}\end{array}$ & $\begin{array}{c}-1.726 \\
(0.186)^{* * *}\end{array}$ & $\begin{array}{c}-1.853 \\
(0.253)^{* * *}\end{array}$ & $\begin{array}{c}0.924 \\
(0.207)^{* * *}\end{array}$ & $\begin{array}{l}-0.172 \\
(0.179)\end{array}$ & $\begin{array}{c}1.679 \\
(0.329)^{* * *}\end{array}$ \\
\hline $\begin{array}{l}\log (\text { mean weekly } \\
\text { manufacturing wage })\end{array}$ & $\begin{array}{c}0.535 \\
(0.164)^{* * *}\end{array}$ & $\begin{array}{c}0.768 \\
(0.173)^{* * *}\end{array}$ & $\begin{array}{l}0.312 \\
(0.257)\end{array}$ & $\begin{array}{c}0.054 \\
(0.202)\end{array}$ & $\begin{array}{c}0.388 \\
(0.166)^{* *}\end{array}$ & $\begin{array}{l}-0.145 \\
(0.334)\end{array}$ \\
\hline $\begin{array}{l}\log (\text { state population: } \\
18 \text { to } 19 \text { year olds })\end{array}$ & $\begin{array}{c}-0.387 \\
(0.129) * * *\end{array}$ & $\begin{array}{c}0.190 \\
(0.141)\end{array}$ & $\begin{array}{c}-0.906 \\
(0.200)^{* * *}\end{array}$ & $\begin{array}{c}0.297 \\
(0.160)^{*}\end{array}$ & $\begin{array}{c}0.290 \\
(0.135)^{* *}\end{array}$ & $\begin{array}{c}0.425 \\
(0.259)\end{array}$ \\
\hline $\begin{array}{l}\log (\text { number high school } \\
\text { graduates, state })\end{array}$ & $\begin{array}{c}0.226 \\
(0.052)^{* * *}\end{array}$ & $\begin{array}{c}0.265 \\
(0.056)^{* * *}\end{array}$ & $\begin{array}{c}0.227 \\
(0.080)^{* * *}\end{array}$ & $\begin{array}{c}0.008 \\
(0.064)\end{array}$ & $\begin{array}{l}-0.017 \\
(0.053)\end{array}$ & $\begin{array}{l}0.035 \\
(0.104)\end{array}$ \\
\hline Year fixed effect & Yes & Yes & Yes & Yes & Yes & Yes \\
\hline Institution fixed effect & Yes & Yes & Yes & Yes & Yes & Yes \\
\hline Constant & $\begin{array}{c}22.090 \\
(2.360)^{* * *}\end{array}$ & $\begin{array}{c}14.198 \\
(2.376)^{* * *}\end{array}$ & $\begin{array}{c}30.344 \\
(3.847)^{* * *}\end{array}$ & $\begin{array}{l}-5.833 \\
(2.914)^{* *}\end{array}$ & $\begin{array}{c}4.273 \\
(2.281)^{*}\end{array}$ & $\begin{array}{l}-14.690 \\
(4.991)^{* * *}\end{array}$ \\
\hline $\begin{array}{l}\text { Observations/number } \\
\text { of institutions }\end{array}$ & $4190 / 427$ & $1792 / 180$ & $2398 / 247$ & $4190 / 427$ & $1792 / 180$ & $2398 / 247$ \\
\hline$R^{2}$ (within) & 0.28 & 0.53 & 0.19 & 0.08 & 0.08 & 0.11 \\
\hline
\end{tabular}

Coefficient estimates are from fixed-effects models controlling for institution-specific unobserved heterogeneity. Dependent variables are $\log$ (enrollments), where enrollment means for columns 1 through 6 are 1219, 2232, 462, 3269, 6145, and 1120, respectively. The sample period is 1988 through 1997. Standard errors in parentheses.

* Significant at $10 \%$.

$* *$ Significant at $5 \%$.

$* * *$ Significant at $1 \%$.

patterns across measures of quality. We assign Selective ${ }_{i}=1$ to institution $i$ where the entrance requirements are reported as "very difficult" or "most difficult" in Peterson's 1989 Guide to FourYear Colleges. In order to capture the potential for relative selectivity at a more local level, we also augment Selective ${ }_{i}$ to equal one if institution $i$ is at or above the 60th percentile within the state in any one of the following indices: the percentage of incoming freshmen with math SAT scores above 500, the percentage of incoming freshmen with verbal SAT scores above 500, or the percentage of incoming freshmen with ACT scores above $21{ }^{11}$ In addition to allowing the effect of HOPE to differ by selectivity, Table 4 reports enrollment responses to HOPE first for all four-year institutions and then separately for public and private institutions.

Across all four-year institutions, the results of Table 4 confirm that both Pell and non-Pell enrollment responses to HOPE are concentrated at less selective institutions. Overall, point estimates suggest that while Pell enrollment increases by $31 \%$ at less selective four-year institutions, otherwise similar but more selective institutions experience only a $7 \%$ increase (column 1). Likewise, however, non-Pell enrollments exhibit a similar pattern, with less selective institutions increasing enrollment by

\footnotetext{
${ }^{11}$ This simple rule was devised to limit school-specific subjectivity. The Appendix reports the institutions qualifying as Selective $=1$ according to this rule. Results are generally robust to an alternative threshold (e.g., using the top $20 \%$ for these measures).
} 
13\% compared with $4 \%$ at more selective institutions (column 4). Separating institutions into public and private universities reveals that overall enrollment responses are larger at public institutions$27 \%$ at public institutions versus $16 \%$ at private institutions. With the slower and less generous introduction of HOPE awards at four-year private institutions, it is not surprising that the Pell enrollment response is smaller at private institutions. ${ }^{12}$ That non-Pell enrollments respond so strongly at private institutions is somewhat surprising and may be evidence of financially able students moving toward private institutions as the propensity for less financially able students to enroll in public institutions increases (Table 4, column 2). On the other hand, to the general extent that there are any significant increases in Pell and non-Pell enrollment at selective four-year institutions (i.e., the net effect implied in columns 1 and 4), such increases are driven by selective private universities.

Overall, our analysis suggests a clear and systematic change in the distribution of Pell students across institutions in Georgia associated with the introduction of the HOPE scholarship - a change that is not seen in other southern states. The larger expansion in the number of Pell recipients at less selective institutions likely reflects the greater capacity constraints at more selective institutions that often have an applicant pool exceeding the number of possible enrollees for a given class. The joint effect of capacity constraints along with greater incentive for top high school students to remain in state for college is consistent with the significant shift in the enrollment of Pell recipients toward less academically selective institutions. Thus, while the HOPE scholarship appears to have improved access of Pell recipients even at the more selective schools, it has consequently induced greater enrollment increases at less selective institutions. Moreover, the relative shift in enrollments toward less selective schools is more pronounced for non-Pell students, suggesting that the HOPE scholarship did not relatively disadvantage needy students at the best schools in Georgia.

\section{Sensitivity of Enrollment Specifications}

Throughout the analysis, sensitivity tests to the sample and the specification confirm the robustness of the results. For example, we test for sample sensitivity by discarding other southern states that introduced merit-based aid programs during our sample period, as in Dynarski (2004). In particular, we discard 29 institutions (287 observations) in Arkansas (which introduced a merit-aid program in 1991), 65 (639) in Mississippi (which began in 1996), and 32 (314) in Florida (which began in 1997). ${ }^{13}$ In all cases, the qualitative conclusions are unchanged.

The enrollment models are specified following prior enrollment studies using similar data and similar samples of institutions. Nonetheless, we also test the sensitivity of the results to our specification. For example, specifications that include institution-specific tuition values or statespecific unemployment rates, or that exclude the number of 18 to 19 year olds, each yield qualitatively similar findings to those presented. ${ }^{14}$ We also repeat all specifications in Tables 3 and 4 with less

${ }^{12}$ Specifically, payments to private university enrollees were $\$ 500$ in 1993, \$1000 in 1994, \$1500 in 1995, and \$3000 in 1996 and 1997.

${ }^{13}$ Outside of New Mexico, which introduced merit aid in 1997, all of the merit-based aid programs were located in the SREB during our sample period. For current statistics on merit offerings nationally, see www.ecs.org.

${ }^{14}$ While IPEDS does include a cell for state appropriations, endowments, etc., these data are sufficiently incomplete that their inclusion would seem to be excessively costly in other dimensions. For example, requiring that state appropriations be reported forces us to discard a full one-third of the institutions in our reported sample. We did test the models with additional institutional controls, however, and the reported results are robust to such controls, where available. With that said, for reporting institutions, an analysis of the data reveals relatively little variation in the time series of such measures, which would suggest that average differences are likely being picked up in the institution fixed effects currently included in the original specifications. 
restricted models, which allow enrollments in institutions in states that share a border with Georgia to differ from those that do not. ${ }^{15}$ These "border effect" specifications suggest that enrollment increases observed in Georgia following HOPE should not be interpreted as drawing strongly from institutions in neighboring states, for such institutions experience small increases in enrollments relative to the remaining southern institutions. Nonetheless, the primary findings regarding the enrollment effects of HOPE for Pell and non-Pell students in Georgia are unaltered by permitting border effects.

Likewise, given the potential sensitivity of difference-in-difference specifications to trends that are specific to treatment or nontreatment groups, other specifications follow Dynarski (2004) in including a Georgia-specific trend (i.e., a "pretreatment trend") to control for such differences. As in Dynarski (2004), we find that pretreatment trends do not explain the observed effect of HOPE on enrollment. We also follow Bertrand, Duflo, and Mullainathan (2004) in accounting for the serialcorrelation problems associated with difference in difference estimation and the possible biases in estimating the standard error around the effect of the HOPE scholarship. In particular, we ignore the time series component in the estimation by calculating an average before and after the introduction of the HOPE scholarship, and then we estimate the equations on this averaged outcome variable as a panel of length two. Given the small standard errors across the variables of interest, our expectation was that no coefficients would lose significance. This is indeed the case, and the qualitative results remain.

The qualitative conclusions are also robust to changes in the HOPE program that occurred during the sample period. For example, after netting out variation in average enrollments (or award values) across years or across institutions with the inclusion of year and institution fixed effects, our reported specifications implicitly restrict the effect of HOPE in 1993 and 1994 to equal that in 1995, 1996, and 1997. However, with respect to Pell enrollments, one should not anticipate significant implications of the 1995 income cap removal, since this pertained only to nonneedy students who, with or without the requirement to file, would not receive Pell assistance (e.g., the National Center for Education Statistics, table 414,1998 , reports that $90 \%$ of student participants in the two largest federal aid programs, the Stafford loan and the Pell grant, have family incomes below \$40,000). Further, with data on Pell enrollments not available by class within institutions (i.e., freshman, sophomore, etc.), we would naturally expect the effect of HOPE on Pell enrollments to appear higher in later years. In fact, without Pell enrollments available by individual classes within institutions, one is unable to separately identify the effect of such a change in policy. When analyzed, the data reveal a slight bump in Georgia Pell enrollments at four-year institutions after 1995, which we interpret as an artifact of using campus-wide enrollments. We find no such bump at two-year institutions or in non-Pell enrollments, generally, and suggest that this may be evidence that the income cap had an unperceivable effect on non-Pell enrollments.

\section{Pell Dollar Allocations and the Georgia HOPE Scholarship}

\section{Average Pell Awards}

Since increases in the number of Pell recipients in Georgia are consistent with HOPE having changed the margin at which it is worthwhile to attend college, the ex post distribution of need among Pell recipients and the corresponding dollar values of Pell support are also likely to have changed.

\footnotetext{
${ }^{15}$ Our purpose in specifically allowing the border institutions to differ assumes that Georgia residents may, on average, find outof-state but neighboring institutions more attractive than those farther from home. If, for example, Georgia students are attending institutions in Florida with higher frequency than those in West Virginia, HOPE may have differentially drawn students back to Georgia from Florida (i.e., a border state).
} 
Table 5. Sensitivity of Average Pell Awards at Georgia Institutions with the Introduction of the HOPE Scholarship

\begin{tabular}{lccccc}
\hline & & \multicolumn{3}{c}{ Four Year } & \\
\cline { 3 - 5 } & All & Pooled & Public & Private & Two Year \\
Independent Variable & $(1)$ & $(2)$ & $(3)$ & $(4)$ & $(5)$ \\
\hline HOPE $\times$ GA institution & -0.043 & 0.033 & 0.029 & 0.030 & -0.129 \\
& $(0.008)^{* * *}$ & $(0.006)^{* * *}$ & $(0.006)^{* * *}$ & $(0.009)^{* * *}$ & $(0.013)^{* * *}$ \\
HOPE $\times$ GA institution $\times$ & -0.064 & -0.047 & -0.071 & -0.023 & \\
Selective & $(0.017)^{* * *}$ & $(0.010)^{* * *}$ & $(0.013)^{* * *}$ & $(0.014)^{*}$ & \\
$\log ($ per capita personal income) & 0.277 & -0.052 & 0.095 & -0.189 & 0.804 \\
& $(0.065)^{* * *}$ & $(0.047)$ & $(0.059)$ & $(0.066)^{* * *}$ & $(0.104)^{* * *}$ \\
$\log ($ mean weekly & 0.209 & -0.124 & -0.201 & -0.068 & 0.350 \\
manufacturing wage) & $(0.066)^{* * *}$ & $(0.046)^{* * *}$ & $(0.055)^{* * *}$ & $(0.067)$ & $(0.111)^{* * *}$ \\
$\log ($ state population: 18 to & -0.070 & 0.084 & 0.249 & -0.098 & -0.147 \\
19 year olds) & $(0.051)$ & $(0.037)^{* *}$ & $(0.045)^{* * *}$ & $(0.052)^{*}$ & $(0.083)^{*}$ \\
$\log ($ number high school & 0.018 & -0.017 & 0.035 & -0.037 & 0.009 \\
graduates, state) & $(0.020)$ & $(0.015)$ & $(0.018)^{* *}$ & $(0.021)^{*}$ & $(0.033)$ \\
Year fixed effect & Yes & Yes & Yes & Yes & Yes \\
Institution fixed effect & Yes & Yes & Yes & Yes & Yes \\
Constant & -5.303 & -1.448 & -4.973 & 2.006 & -10.413 \\
& $(0.948)^{* * *}$ & $(0.669)^{* *}$ & $(0.754)^{* * *}$ & $(1.000)^{* *}$ & $(1.563)^{* * *}$ \\
Observations/number of & $7432 / 759$ & $4190 / 427$ & $1792 / 180$ & $2398 / 247$ & $3242 / 332$ \\
institutions & & & & & \\
$R^{2}$ (within) & 0.12 & 0.62 & 0.64 & 0.66 & 0.31 \\
\hline
\end{tabular}

Coefficient estimates are from fixed-effects models controlling for institution-specific unobserved heterogeneity. Dependent variables are $\log$ (Average Pell Award), with level means for columns 1 through 5 of $\$ 1319, \$ 1445, \$ 1441, \$ 1448$, and \$1157, respectively. The sample period is 1988 through 1997. Standard errors in parentheses.

* Significant at $10 \%$.

** Significant at $5 \%$.

*** Significant at $1 \%$.

Thus, we apply the models in section 3 to an analysis of the average value of Pell awards to examine the average need among Pell recipients at given institutions. As in the presentation of earlier results, we again separate two-year from four-year institutions and distinguish between public and private four-year institutions. Within four-year specifications, we also allow the effect of HOPE to differ by selectivity in a manner similar to earlier specifications.

With respect to average Pell award values at institutions in Georgia relative to other southern states, a pooled sample of institutions reveals that the average award value declines by $4.2 \%$ at less selective institutions after HOPE and by $10.1 \%$ at selective institutions (Table 5, column 1). Overall, pooled sample estimates suggest that HOPE may have drawn less needy students, who might not otherwise have sought federal aid either because of uncertainty regarding the provision of aid or because the level of expected support was insufficient to warrant the effort, into the pool of applicants. This effect is most evident at two-year institutions, where HOPE is associated with a $13 \%$ decline in average award value (column 5). However, subsequent specifications further reveal that average award values also vary with HOPE differently at two- and four-year institutions. In fact, columns 2 through 4 in Table 5 reveal positive award value responses to HOPE at less selective four-year institutions, both public and private. Further, among a sample of private institutions, point estimates suggest that average award values are everywhere positively associated with HOPE, but lower at the selective institutions among this class. 
Table 6. Sensitivity of Total Pell Revenue at Georgia Institutions with the Introduction of the HOPE Scholarship

\begin{tabular}{lccccc}
\hline & & \multicolumn{3}{c}{ Four Year } & \\
\cline { 3 - 5 } & All & Pooled & Public & Private & Two Year \\
Independent Variable & $(1)$ & $(2)$ & $(3)$ & $(4)$ & $(5)$ \\
\hline HOPE $\times$ GA institution & 0.184 & 0.302 & 0.362 & 0.218 & 0.060 \\
& $(0.022)^{* * *}$ & $(0.022)^{* * *}$ & $(0.022)^{* * *}$ & $(0.035)^{* * *}$ & $(0.035)^{*}$ \\
HOPE $\times$ GA institution $\times$ & -0.297 & -0.243 & -0.371 & -0.104 & \\
Selective & $(0.046)^{* * *}$ & $(0.037)^{* * *}$ & $(0.043)^{* * *}$ & $(0.054)^{*}$ & \\
$\log ($ per capita personal income) & -1.234 & -1.775 & -1.630 & -2.042 & -0.087 \\
& $(0.176)^{* * *}$ & $(0.177)^{* * *}$ & $(0.200)^{* * *}$ & $(0.262)^{* * *}$ & $(0.268)$ \\
$\log$ (mean weekly & 0.842 & 0.411 & 0.567 & 0.244 & 0.555 \\
manufacturing wage) & $(0.178)^{* * *}$ & $(0.173)^{* *}$ & $(0.186)^{* * *}$ & $(0.266)$ & $(0.286)^{*}$ \\
$\log$ (state population: 18 to & -0.799 & -0.302 & 0.439 & -1.003 & -1.226 \\
19 year olds) & $(0.137)^{* * *}$ & $(0.136)^{* *}$ & $(0.151)^{* * *}$ & $(0.206)^{* * *}$ & $(0.215)^{* * *}$ \\
$\log ($ number high school & 0.258 & 0.210 & 0.300 & 0.190 & 0.199 \\
graduates, state) & $(0.055)^{* * *}$ & $(0.054)^{* * *}$ & $(0.060)^{* * *}$ & $(0.082)^{* *}$ & $(0.084)^{* *}$ \\
Year fixed effect & Yes & Yes & Yes & Yes & Yes \\
Institution fixed effect & Yes & Yes & Yes & Yes & Yes \\
Constant & 17.972 & 20.642 & 9.225 & 32.349 & 14.040 \\
& $(2.547)^{* * *}$ & $(2.489)^{* * *}$ & $(2.556)^{* * *}$ & $(3.972)^{* * *}$ & $(4.036)^{* * *}$ \\
Observations/number & $7432 / 759$ & $4190 / 427$ & $1792 / 180$ & $2398 / 247$ & $3242 / 332$ \\
of institutions & & & & & \\
$R^{2}$ (within) & 0.28 & 0.22 & 0.44 & 0.17 & 0.55 \\
\hline
\end{tabular}

Coefficient estimates are from fixed-effects models controlling for institution-specific unobserved heterogeneity. Dependent variables are $\log$ (Total Pell Revenue), with level means $(100,000 \mathrm{~s})$ for columns 1 through 5 of $\$ 15.2, \$ 17.7, \$ 32.4$, $\$ 6.8$, and \$11.8, respectively. The sample period is 1988 through 1997. Standard errors in parentheses.

* Significant at $10 \%$.

$* *$ Significant at $5 \%$.

$* * *$ Significant at $1 \%$.

\section{Total Pell Revenue}

The asymmetric responses found for both enrollment and average Pell awards imply that annual Pell disbursements to institutions, which equals enrollment times the average Pell award, might also respond likewise. Thus, the specification used to estimate enrollment and average Pell awards in section 3 is also used to examine the response of annual institutional Pell revenues to HOPE, reflecting its joint enrollment and level-of-aid effects. These results are presented in Table 6.

In considering the variation in total annual Pell disbursements to institutions associated with HOPE, Table 6 reveals similar patterns, with two notable exceptions. First, while the average award value at selective four-year institutions in Georgia declines (Table 5, column 2), Pell enrollment responses at these same institutions are sufficiently large so that the total Pell revenue received is $6.1 \%$ higher following the introduction of HOPE (Table 6, column 2). However, analyzing public and private institutions separately suggests that this net positive result is driven by private institutions, since total Pell revenue collected by selective public institutions actually declines with HOPE, although the effect is small in magnitude (column 3). A second exception to the pattern of average award values is specific to two-year institutions, where enrollment responses are again large enough in magnitude to yield a net positive effect of HOPE on total revenues. In particular, while average awards decline by roughly 13\% (Table 5, column 5), the 19\% enrollment increase (Table 3, column 2) 
yields a 6\% net increase in total disbursements to the average two-year institution in Georgia, relative to the control (Table 6, column 5). ${ }^{16}$

Overall, from a fiscal standpoint, the results are consistent with Georgia being able to leverage its scholarship dollars with greater federal support. This leveraging effect is, nonetheless, concentrated among two-year institutions and less selective four-year public institutions, where Pell students are historically more likely to enroll, and at private four-year institutions, where students may be more responsive to the offering of merit aid in Georgia.

\section{The Effect of Race: An Analysis of Historically Black Colleges and Universities}

Initially, our findings with regard to Pell enrollments and revenues might appear inconsistent with other indirect evidence regarding the impact of the HOPE scholarship on low-income students. Specifically, Dynarski (2000) used the CPS to show that the HOPE scholarship raised the probability that white students enrolled in Georgia institutions by $12 \%$ relative to those in other southern states, but had an insignificant (although positive) enrollment effect on African-American students. To the extent that our direct measure of need (i.e., Pell status) correlates positively with minority status, that African-American students appear less responsive may be viewed as contrary to our findings that HOPE expanded enrollment among needy populations. Unfortunately, a direct examination of the racial composition of Pell recipients is not possible, since the Pell data provide no indication of racial demographic groups.

However, racial differences in the impact of the HOPE scholarship can be examined indirectly by exploiting the patterns observed in a sample of historically black colleges and universities (HBCUs). The enrollment results for Pell and non-Pell students, along with results for average Pell awards and total Pell revenue, are reported for this sample of institutions in Table 7. Consistent with our prior findings, Pell enrollments at HBCUs are more responsive to HOPE than are the enrollments of nonneedy students. In particular, the number of Pell recipients increased by $15 \%$ at HBCUs in Georgia in the post-HOPE period relative to HBCUs in other southern states, whereas the comparative increase for non-Pell enrollment is insignificant. Thus, while we support the findings in Dynarski (2000) insofar as non-Pell enrollments at HBCUs show no change with HOPE, our results do suggest that HOPE had a positive enrollment impact on low-income African Americans.

Interestingly, HBCUs differ from the broader set of four-year institutions in Georgia, with the effects of HOPE falling between those estimated for two- and four-year institutions in general. For example, the point estimates in Table 7 indicate that average Pell awards did not change significantly in the post-HOPE period relative to other southern states, as compared to a decline at two-year institutions and increase at other four-year institutions. Nonetheless, to more fully understand how and why AfricanAmerican students and HBCUs appear to have benefited differently from the HOPE scholarship requires further study using individual-level data with institutional information that are not currently available.

\section{Discussion and Concluding Remarks}

A stated goal of U.S. financial policy since the Serviceman's Readjustment Act in 1944 has been to ensure college access independent of need. Even so, federal support for need-based grants

\footnotetext{
${ }^{16}$ The 1993 increase in the Pell cap might be expected to increase the average Pell award in all states but should not be expected to affect our relative comparisons of the average Pell across states unless Georgia schools are more expensive than those in other states (which they are not). In any case, the direction of the bias would work against our findings of a decrease in the average Pell award after HOPE.
} 
Table 7. Sensitivity of Enrollments at Georgia HBCUs with the Introduction of the HOPE Scholarship

\begin{tabular}{|c|c|c|c|c|}
\hline \multirow[b]{2}{*}{ Independent Variable } & \multicolumn{2}{|c|}{ HBCU Enrollment } & \multicolumn{2}{|c|}{ Revenue } \\
\hline & $\begin{array}{l}\log (\text { Pell } \\
\text { Enrollment }) \\
\text { (1) }\end{array}$ & $\begin{array}{l}\log (\text { Non-Pell } \\
\text { Enrollment) } \\
\text { (2) }\end{array}$ & $\begin{array}{l}\log \text { (Average } \\
\text { Pell Award) } \\
\text { (3) }\end{array}$ & $\begin{array}{c}\log (\text { Total } \\
\text { Pell Revenue }) \\
\text { (4) }\end{array}$ \\
\hline HOPE $\times$ GA institution & $\begin{array}{c}0.150 \\
(0.043)^{* * *}\end{array}$ & $\begin{array}{c}0.071 \\
(0.077)\end{array}$ & $\begin{array}{l}-0.020 \\
(0.013)\end{array}$ & $\begin{array}{c}0.130 \\
(0.043)^{* * *}\end{array}$ \\
\hline $\log ($ per capita personal income) & $\begin{array}{c}-1.886 \\
(0.447)^{* * *}\end{array}$ & $\begin{array}{c}0.376 \\
(0.806)\end{array}$ & $\begin{array}{c}0.154 \\
(0.139)\end{array}$ & $\begin{array}{c}-1.732 \\
(0.452)^{* * *}\end{array}$ \\
\hline $\begin{array}{l}\log (\text { mean weekly } \\
\text { manufacturing wage })\end{array}$ & $\begin{array}{l}-0.250 \\
(0.465)\end{array}$ & $\begin{array}{c}0.105 \\
(0.838)\end{array}$ & $\begin{array}{l}-0.041 \\
(0.145)\end{array}$ & $\begin{array}{l}-0.291 \\
(0.470)\end{array}$ \\
\hline $\begin{array}{l}\log \text { (state population: } 18 \text { to } \\
19 \text { year olds) }\end{array}$ & $\begin{array}{l}-0.533 \\
(0.338)\end{array}$ & $\begin{array}{c}0.241 \\
(0.609)\end{array}$ & $\begin{array}{c}0.147 \\
(0.105)\end{array}$ & $\begin{array}{l}-0.386 \\
(0.342)\end{array}$ \\
\hline $\begin{array}{l}\log (\text { number high school } \\
\text { graduates, state) }\end{array}$ & $\begin{array}{c}-0.470 \\
(0.143)^{* * *}\end{array}$ & $\begin{array}{l}-0.098 \\
(0.258)\end{array}$ & $\begin{array}{c}-0.118 \\
(0.045)^{* * *}\end{array}$ & $\begin{array}{c}-0.589 \\
(0.145)^{* * *}\end{array}$ \\
\hline Year fixed effect & Yes & Yes & Yes & Yes \\
\hline Institution fixed effect & Yes & Yes & Yes & Yes \\
\hline Constant & $\begin{array}{c}38.154 \\
(6.021)^{* * *}\end{array}$ & $\begin{array}{c}0.073 \\
(10.859)\end{array}$ & $\begin{array}{l}-3.513 \\
(1.873)^{*}\end{array}$ & $\begin{array}{c}34.641 \\
(6.090)^{* * *}\end{array}$ \\
\hline $\begin{array}{l}\text { Observations/number } \\
\text { of institutions } \\
R^{2} \text { (within) }\end{array}$ & $\begin{array}{c}778 / 81 \\
019\end{array}$ & $778 / 81$ & $778 / 81$ & $778 / 81$ \\
\hline$R^{2}$ (within) & 0.19 & 0.12 & 0.38 & 0.16 \\
\hline
\end{tabular}

Coefficient estimates are from fixed-effects models controlling for institution-specific unobserved heterogeneity. Dependent variables in columns 1 and 2 have mean values (not logged) of 1390 and 1141. Dependent variables in columns 3 and 4 have mean values (not logged) of \$1522 and \$2,202,605. The sample period is 1988 through 1997.

Standard errors in parentheses.

* Significant at $10 \%$.

** Significant at $5 \%$.

$* * *$ Significant at $1 \%$.

and loans has not kept pace with the rising cost of college over several decades, and rising competition within higher education has led to greater reliance by states and universities on meritbased aid to attract and retain the best college students. Consequently, subsidized, need-based aid has become a decreasing share of the average financial aid package, and there is increasing concern among higher education administrators and policy makers that needy students do not have access to a college education. Nonetheless, few studies have examined whether the adoption of broadbased, merit-aid programs work with or against the universal college access objectives of need-based programs.

In this paper, we exploit the 1993 introduction of the Georgia HOPE scholarship, which paid tuition, fee, and book expenses for all Georgia high school graduates who earned at least a 3.0 grade point average, to study how merit aid affects the college access of Pell and non-Pell students in Georgia relative to other southern states. Specifically, new institution-level data on the number of Pell students and their level of assistance are merged with institution-specific and state-level data drawn primarily from the IPEDS data available on the National Center for Educational Statistics Web site for the years 1988 thorough 1997. These data are used to estimate the impact of the Georgia HOPE scholarship on the number of Pell and non-Pell students and the average and total Pell award in Georgia versus other southern institutions, controlling for time-varying institutional and state-specific factors and conditioned on institution-level fixed effects.

The results provide some of the first formal evidence that broad-based increases in merit aid can 
improve the college access of needy students but also suggest that the institution-specific increases in the number of Pell recipients and total Pell receipts are concentrated among two-year and less selective four-year institutions. Therefore, while the HOPE scholarship successfully achieves its stated intent of retaining the most able students in Georgia (e.g., Cornwell and Mustard 2002), the data do not suggest that HOPE harms the opportunities of Pell students at the most selective institutions. In fact, needy students seem to have benefited with the introduction of merit aid in a similar way as more financially able students. The apparent beneficial effects of the HOPE scholarship on needy students might be expected to be even larger with the administrative rule change in 2000 that no longer reduces the scholarship award dollar per dollar with Pell. On the other hand, as of 2001, lowincome students are no longer required to complete the FAFSA in order to receive HOPE. It follows that low-income Georgia students face a reduced incentive to participate in the Pell program, which might well change the mix of students who are deemed to be needy and the apparent ability of the state to leverage state dollars with federal dollars. Thus, the long-term effects of the Georgia HOPE scholarship on needy students cannot be safely speculated.

While we provide the first step in studying how a state-specific merit-aid program may affect the college access of needy students, the broader fiscal effects suggest that the allocation of Pell dollars across the population of institutions may well be zero sum. Thus, as the trend toward merit aid continues, with 20 such programs in existence by 2005 , the general-equilibrium effects are an important avenue of future research.

\title{
Appendix
}

Institutions in Southern States for which Selective $=1$

\author{
ALABAMA \\ AUBURN UNIVERSITY \\ HUNTINGDON COLLEGE \\ SAMFORD UNIVERSITY \\ SOUTHEASTERN BIBLE COLLEGE \\ SPRING HILL COLLEGE \\ UNIVERSITY OF ALABAMA \\ UNIVERSITY OF ALABAMA-HUNTSVILLE

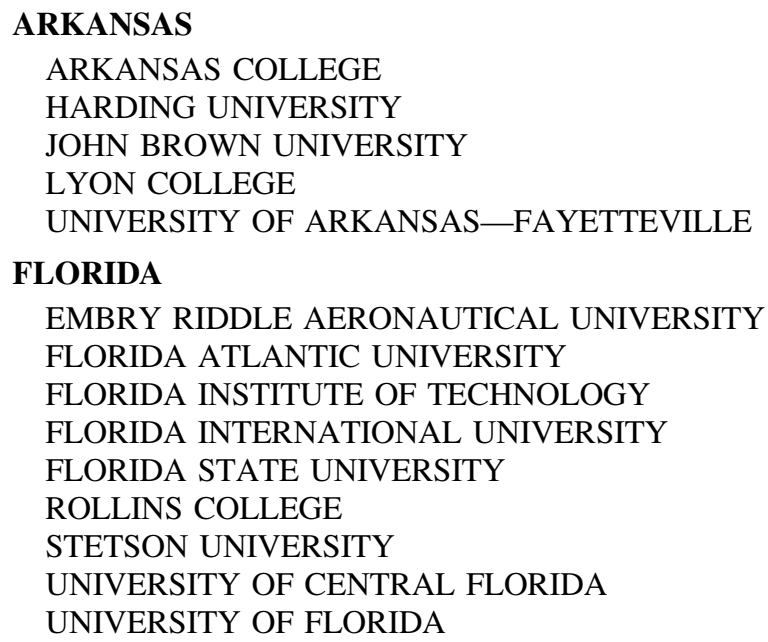

ARKANSAS COLLEGE

HARDING UNIVERSITY

JOHN BROWN UNIVERSITY

LYON COLLEGE

UNIVERSITY OF ARKANSAS-FAYETTEVILLE

\section{FLORIDA}

EMBRY RIDDLE AERONAUTICAL UNIVERSITY

FLORIDA ATLANTIC UNIVERSITY

FLORIDA INSTITUTE OF TECHNOLOGY

FLORIDA INTERNATIONAL UNIVERSITY

FLORIDA STATE UNIVERSITY

ROLLINS COLLEGE

STETSON UNIVERSITY

UNIVERSITY OF CENTRAL FLORIDA

UNIVERSITY OF FLORIDA 


\section{Appendix}

Continued

UNIVERSITY OF MIAMI

UNIVERSITY OF NORTH FLORIDA

\section{GEORGIA}

BERRY COLLEGE

EMORY UNIVERSITY

GEORGIA COLLEGE

GEORGIA INSTITUTE OF TECHNOLOGY

MERCER UNIVERSITY

OGLETHORPE UNIVERSITY

SAVANNAH COLLEGE OF ART AND DESIGN

SHORTER COLLEGE

SOUTHERN COLLEGE OF TECHNOLOGY

SPELMAN COLLEGE

UNIVERSITY OF GEORGIA

WESLEYAN COLLEGE

\section{KENTUCKY}

ASBURY COLLEGE

GEORGETOWN COLLEGE

KENTUCKY WESLEYAN COLLEGE

THOMAS MORE COLLEGE

TRANSYLVANIA UNIVERSITY

\section{LOUISIANA}

CENTENARY COLLEGE OF LOUISIANA

LOUISIANA TECH UNIVERSITY

LOYOLA UNIVERSITY

TULANE UNIVERSITY OF LOUISIANA

UNIVERSITY OF NEW ORLEANS

\section{MARYLAND}

GOUCHER COLLEGE

HOOD COLLEGE

JOHNS HOPKINS UNIVERSITY

LOYOLA COLLEGE

ST. MARY'S COLLEGE OF MARYLAND

UNIVERSITY MARYLAND-COLLEGE PARK

UNIVERSITY MARYLAND—BALTIMORE COUNTY

WASHINGTON COLLEGE

\section{MISSISSIPPI}

BELHAVEN COLLEGE

DELTA STATE UNIVERSITY

MISSISSIPPI STATE UNIVERSITY

UNIVERSITY OF MISSISSIPPI

UNIVERSITY OF SOUTHERN MISSISSIPPI

\section{NORTH CAROLINA}

APPALACHIAN STATE UNIVERSITY

CAMPBELL UNIVERSITY

CATAWBA COLLEGE

DUKE UNIVERSITY

GUILFORD COLLEGE 


\section{Appendix}

Continued

HIGH POINT UNIVERSITY

LENOIR-RHYNE COLLEGE

MARS HILL COLLEGE

METHODIST COLLEGE

NORTH CAROLINA STATE UNIVERSITY-RALEIGH

QUEENS COLLEGE

SALEM COLLEGE

ST. ANDREWS PRESBYTERIAN COLLEGE

ST. AUGUSTINES COLLEGE

UNIVERSITY OF NC-ASHEVILLE

UNIVERSITY OF NC-CHAPEL HILL

UNIVERSITY OF NC-CHARLOTTE

UNIVERSITY OF NC-GREENSBORO

UNIVERSITY OF NC-WILMINGTON

WAKE FOREST UNIVERSITY

\section{OKLAHOMA}

OKLAHOMA BAPTIST UNIVERSITY

OKLAHOMA CITY UNIVERSITY

OKLAHOMA PANHANDLE STATE UNIVERSITY

OKLAHOMA STATE UNIV-AGR/APPL SCI

UNIVERSITY OF OKLAHOMA

UNIVERSITY OF SCI \& ARTS OF OKLAHOMA

UNIVERSITY OF TULSA

\section{SOUTH CAROLINA}

CITADEL THE MILITARY COLLEGE

CLEMSON UNIVERSITY

COLLEGE OF CHARLESTON

CONVERSE COLLEGE

FURMAN UNIVERSITY

PRESBYTERIAN COLLEGE

\section{TENNESSEE}

BELMONT COLLEGE

BELMONT UNIVERSITY

CHRISTIAN BROTHERS COLLEGE

CHRISTIAN BROTHERS UNIVERSITY

DAVID LIPSCOMB UNIVERSITY

KING COLLEGE

LINCOLN MEMORIAL UNIVERSITY

MARYVILLE COLLEGE

MEMPHIS STATE UNIVERSITY

MILLIGAN COLLEGE

TENNESSEE TECHNOLOGICAL UNIVERSITY

UNION UNIVERSITY

UNIVERSITY OF MEMPHIS

VANDERBILT UNIVERSITY

\section{TEXAS}

BAYLOR UNIVERSITY

DALLAS CHRISTIAN COLLEGE 


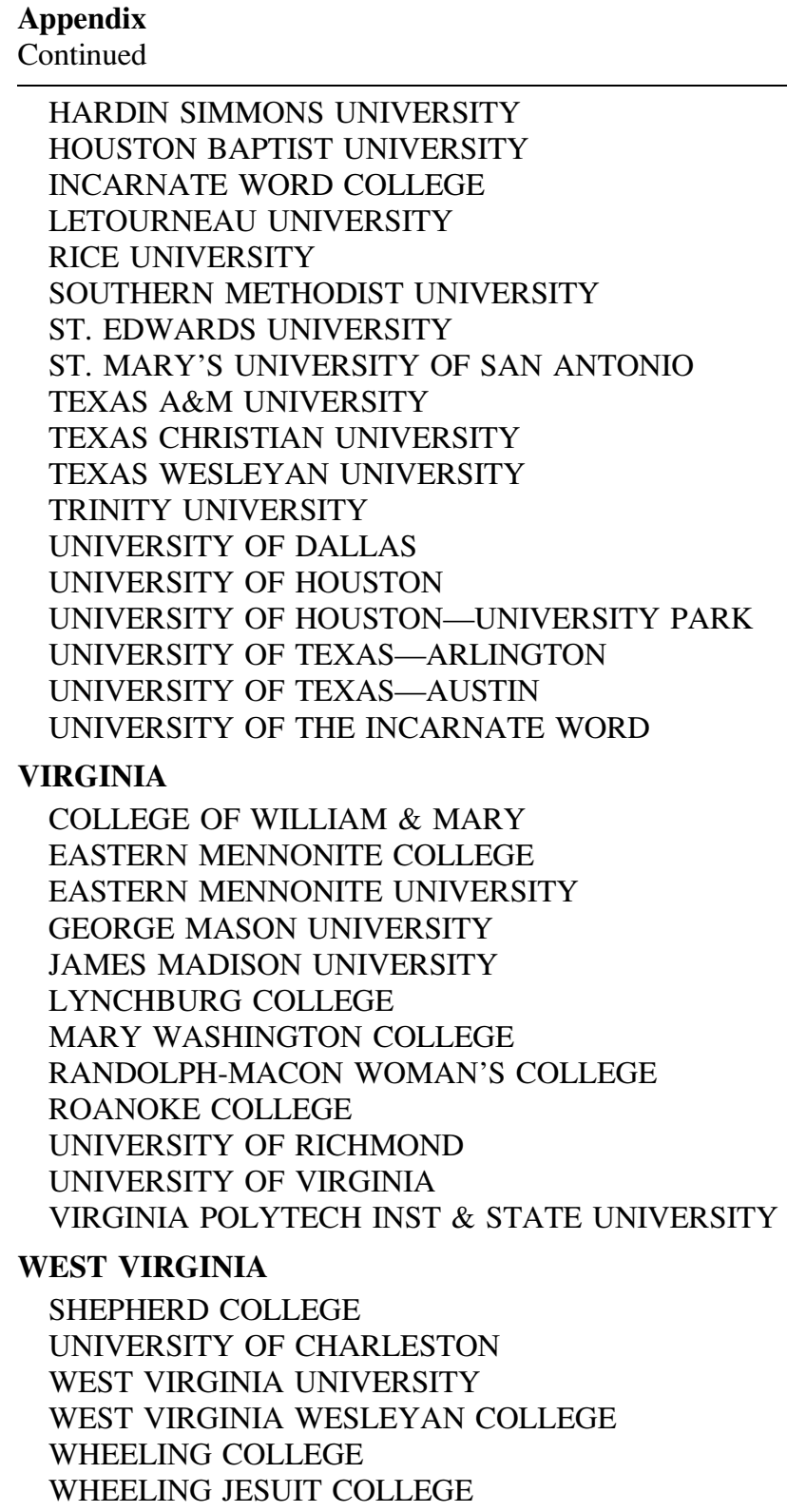

Selective $=1$ if institution $i$ is above the 60th percentile (within state) in any one the following indices: the percentage of incoming freshmen with math SAT scores above 500, the percentage of incoming freshmen with verbal SAT scores above 500, or the percentage of incoming freshmen with ACT scores above 21. Alternatively, institutions are assigned Selective $=1$ where the entrance requirements are reported "very difficult" or "most difficult" in Peterson's 1989 Guide to Four-Year Colleges. 


\section{References}

Balderston, Frederick. 1997. Tuition and financial aid in higher education: The case of California. Economics of Education Review 16:337-43.

Bertrand, Marianne, Esther Duflo, and Sendhil Mullainathan. 2004. How much should we trust difference-in-differences estimates? Quarterly Journal of Economics 119:249-75.

Card, David, and Thomas Lemieux. 2000. Dropout and enrollment trends in the post-war period: What went wrong in the 1970s? NBER Working Paper No. 7658.

Clotfelter, Charles. 2004. The new merit aid: Comment. In College choices: The economics of which college, when college, and how to pay for it, edited by Caroline M. Hoxby. Chicago: University of Chicago Press, pp. 97-100.

Cornwell, Christopher, and David B. Mustard. 2002. HOPE, the brain drain, and diversity: The impact of the scholarship on high achievers and African Americans. Policy Notes 3:4, Carl Vinson Institute of Government, University of Georgia.

Cornwell, Christopher, David B. Mustard, and Deepa J. Sridhar. 2006. The enrollment effects of merit-based aid. Journal of Labor Economics. In press.

Dee, Thomas, and Linda A. Jackson. 1999. Who loses HOPE? Attrition from Georgia's college scholarship program. Southern Economic Journal 66:379-90.

Duffy, Elizabeth A., and Idana Goldberg. 1998. Crafting a class: College admissions and financial aid, 1955-1994. Princeton, NJ: Princeton University Press.

Dynarski, Susan M. 2000. HOPE for whom? Financial aid for the middle class and its impact on college attendance. National Tax Journal 53:629-61.

Dynarski, Susan M. 2003. Does aid matter? Measuring the effect of student aid on college attendance and completion. American Economic Review 93:279-88.

Dynarski, Susan M. 2004. The new merit aid. In College choices: The economics of which college, when college, and how to pay for it, edited by Caroline M. Hoxby. Chicago: University of Chicago Press, pp. 63-97.

Ehrenberg, Ronald G. 2000. Tuition rising: Why college costs so much. Cambridge: Harvard University Press.

Hansen, W. Lee. 1983. Impact of student financial aid on access. In The crisis in higher education, edited by J. Froomkin. New York: Academy of Political Science, pp. 84-96.

Kane, Thomas J. 1995. Rising public college tuition and college entry: How well do public subsidies promote access to college? NBER Working Paper No. 5164.

Long, Bridget T. 2002. How do financial aid policies affect colleges? The institutional impact of the Georgia HOPE scholarship. Working paper, Graduate School of Education, Harvard University.

Manski, Charles F., and David A. Wise. 1983. College choice in America. Cambridge, MA: Harvard University Press.

McPherson, Michael S., and Morton O. Schapiro. 1994. Merit aid: Students, institutions, and society. Consortium for Policy Research in Education Research Report No. 30. August 1994.

McPherson, Michael S., and Morton O. Schapiro. 1998. The student aid game. Princeton, NJ: Princeton University Press.

Rizzo, Michael J., and Ronald G. Ehrenberg. 2003. Resident and nonresident tuition and enrollment at flagship state universities. NBER Working Paper No. 9516.

Seftor, Neil, and Sarah Turner. 2002. Back to school: Federal student aid policy and adult college enrollment. Journal of Human Resources 37:336-52.

Singell, Larry D., Jr., and Joe A. Stone. 2002. The good, the poor, and the wealthy: Who responds most to college financial aid? Bulletin of Economic Research 54:393-407.

Singell, Larry D., Jr., and Joe A. Stone. 2006. For whom the Pell tolls: A test of the Bennett hypothesis. Economics of Education Review. In press. 
Reproduced with permission of the copyright owner. Further reproduction prohibited without permission. 